\title{
The effect of cocoa certification program in increasing production and farmers income in Tapango Barat Village, Tapango District, Polewali Mandar Regency
}

\author{
Burhanuddin $^{1 *}$, Muhammad Arsyad ${ }^{2}$, Kurniati $^{3}$, Makmur $^{4}$, and Indrastuti ${ }^{5}$ \\ 1,3,4,5 Agribusiness Department, Universitas Sulawesi Barat, Indonesia \\ ${ }^{2}$ Socio-economic of Agriculture Department, Universitas Hasanuddin, Indonesia \\ *Corresponding author's e-mail: usb.burhan@yahoo.com
}

Received December 20th, 2019; revised January 30th, 2020; accepted February 14th, 2020

\begin{abstract}
The production of Indonesian cocoa beans is significantly increasing but is not in line with its quality. The quality has decreased such as less fermented, not dry, inconsistency of the size $\mathcal{E}$ taste. Since then, reputation of Indonesia cocoa beans was considered lower than international standard which caused price is relatively cheap compared to other production countries. The low quality of cocoa beans is due to that the age of cocoa plants in Indonesia is more than 17 years so productivity has declined, besides that cocoa pod borer since 1995 until now has not been eradicated 100\%. So, the age of the plant greatly influences the amount of fruit that can be produced. The benefits of cocoa certification program to the farmers production and income are the creation of agribusiness insight and industrial culture in the community, the development of downstream agribusiness subsystem activities in the form of postharvest, processing and marketing activities which ultimately increase farmers' income and welfare through increased production also will increased foreign exchange earnings for Country. Tapango Barat is a cocoa development center area certified by the Rainforest Alliance (RA) from 2015 until now with the aim of describing the cocoa certification program in Tapango Barat Village, calculating the level of farmers' income, and analyzing the effect of the cocoa certification program on increasing farmer production and income. This research was conducted in January - April 2017 using descriptive, income analysis, and multiple regression analysis methods. The results showed that the Mesa Peolo farmer group certified by the Rainforest Alliance (RA) had an income of IDR 17,106,039.073 each year. This shows that the production results from certification program directly influence cocoa farmers' income.
\end{abstract}

Keywords:

Cocoa, Certification program, Production, Income

\section{Introduction}

Polewali Mandar is one of area in Indonesia has supported land resources with strategic location, thereby making the region has considerable opportunities in the development of cocoa. One area that has potentially to develop cocoa cultivations is Tapango District. Cocoa is one of the leading commodities in West Sulawesi. As a non-oil and gas export commodity, cocoa has a dual function as a source of national foreign exchange and able to support local revenue (PAD). This is quite basic because international cocoa prices are currently high enough to be a good momentum for farmers or business people to exploit.

The level of production, productivity and harvested area of cocoa is relatively enhancing in the last ten years. This enhancement followed by increased in export volume and value. The volume and value of cocoa commodity exports are the largest for plantation commodities. The export volume increased by $20.08 \%$, while the export value escalated by $87.74 \%$. One of the reasons export values was raised because the selling price of cocoa beans at the farm level is high. Polewali Mandar Regency is a 
cocoa production center in West Sulawesi. The area of smallholder plantations is $48,889.69$ Ha with the productivity up to 0.7 t.ha ${ }^{-1}$ [1].

Tapango Barat Village is one of the cocoa production areas in Tapango District. Most community livelihoods are planting cocoa. People in the region rely heavily on cocoa as a source of livelihood and depend on these plants. Therefore, this plant is a source of economic income for farm households as well as an economic driver in the Tapango Barat Village.

The issue of cocoa farmers in Tapango Barat village faced before join in the certification program is low productivity. This is due to the farmers' knowledge \& skill of cocoa cultivation is low \& not compliance with the according to standard so the land use still not optimal. So further research needs to be done in order to find out how cocoa certification programs can affect the increase of production and income of farmers in the village of Tapango Barat, District of Tapango, Polewali Mandar Regency. This research has several contributions. First, to determine the suitability of the certification program with technical guidelines. Second, to calculate the income level of certified farmers. Third, to analyze the effect of the cocoa certification program on cocoa farmers' income in Tapango Barat Village.

\section{Method}

This research was conducted in Tapango Barat Village, Tapango Subdistrict, Polewali Mandar District, and the data collection began in January to April 2017. To answer the research questions, data analysis used descriptive, income analysis and multiple regression analysis methods.

\subsection{Analysis of Certified Cocoa Farmer Revenues}

\subsubsection{Revenue}

Total revenue is the result of multiplication of total products that sold with the unit price. As can be seen in the table 1 .

Table 1. Cocoa farmer revenues

\begin{tabular}{|c|c|c|}
\hline No. & Harvest & Revenue (Rp) \\
\hline 1 & I & $1,661,250$ \\
\hline 2 & II & $2,727,083.3$ \\
\hline 3 & III & $5,593,125$ \\
\hline 4 & IV & $8,102,083.3$ \\
\hline 5 & V & $2,837,916.7$ \\
\hline & Total & $20,921,458.3$ \\
\hline
\end{tabular}

Source: Primary data processed (2017)

Based on table 1, the total income received by farmers in five harvests season are in the harvest I, total income is IDR $1,661,250$. This season, the number of revenues is the lowest at all because the yield from cocoa is low and followed by harvest II which is IDR 2,727,083.3 and harvest III is about IDR 5,593,125. In the harvest IV the cacao had already produced a lot of fruit and it was the highest peak phase of the five harvests season is up to IDR 8,102,083.3 and the number of revenues is decline again during in the Harvest V which number is IDR 2,837,916.7. 


\subsubsection{Fixed Cost}

Fixed costs are costs that amount up to a certain level of activity is relatively fixed of the total costs incurred that are not affected by the size of the volume of activity [2].

Table 2. Fixed cost

\begin{tabular}{cll}
\hline No & Type of Fixed Cost & Amount (IDR) \\
\hline 1 & Equipment depreciation & $20,921,458.3$ \\
& a. Hoes & $18,756.625$ \\
& b. Machete & $77,465.25$ \\
& c. Sickle & $12,378.417$ \\
& d. Hand Sprayer & $113,138.83$ \\
& e. Cocoa Scissors & $10,972.125$ \\
& f. Saw & $10,833.208$ \\
& g. Rubber Boots & $20,749.792$ \\
2 & Land Tax $\quad$ Total & $17,106,039.073$ \\
\hline
\end{tabular}

Source: Primary data processed (2017)

Table 2 shows that, fixed costs incurred by each farmer on a number of depreciation tools such as hand sprayers is the highest cost IDR 113,138.83, then the second highest cost is a machete IDR $77,465.25$, while the third fixed cost of depreciation is shoes rubber IDR 20,749,792, and then the fourth fixed cost of depreciation is hoes IDR $18,756,625$, the fifth fixed cost is sickle IDR 12,378,417, and then the sixth fixed cost is brown scissors which about IDR 10,972,125 while the lowest fixed equipment depreciation expense is chainsaw IDR 10,833,208.

\subsubsection{Variable Cost}

Variable costs are cost that amount varies proportionally to changes in the volume of activity but the cost per unit is fixed, which means if the volume of activity is increased 2 (two) times then the total cost will also be 2 (two) times from the original amount [2]. The variable costs incurred by each farmer in cocoa farming can be seen in the table 3.

Based on table 3, the highest total variable costs incurred in harvest 1 by certified cocoa farmers were fertilizer costs of IDR 762,083.33 and herbicide costs at IDR 130,916.67, pesticides at IDR 123,083.33. Labor costs are the lowest costs incurred by farmers in harvest 1 with IDR 31,250.Variable costs incurred by certified farmers, such as nurseries, are the highest costs in the second harvest with a value of IDR 181,878, while the third and fourth harvests were the lowest costs.

The total variable costs incurred by certified cocoa farmers, especially pesticide expenditure sequentially from the highest harvest season I is IDR123,541.67 then in the harvest III IDR 121,458.33, then in the harvestIVIDR112,083.33, then the harvest II is IDR 105,000 and the harvest Vis IDR 81,666.66. The low harvest in season V is due to the reduced number of fruits produced compared to the previous harvest.

The highest herbicide expenditure occurred in the harvest season I IDR 130,916.67 is the highest cost incurred by farmers due to weed prevention activities. Furthermore, the cost spent in the harvest III were IDR60,416.66, then the harvest II was IDR 41,666.66, the IV harvest was IDR35,000 and harvest V was IDR 19,166.66. Harvest Season $V$ is the least cost incurred by farmers each year. 
Furthermore, the highest expenditure on labor costs incurred by certified cocoa farmers occurred in the harvest IV IDR 110,416.67 while the harvest II was the lowest cost incurred by farmers each harvest IDR 27,916.67.

\section{Table 3. Variable Cost}

\begin{tabular}{|c|c|c|}
\hline No & Types of Variable Cost & Amount (IDR) \\
\hline \multirow{6}{*}{1} & Harvest I & \\
\hline & a. Fertilizer & $762,083.33$ \\
\hline & b. Seeds & $43,333.33$ \\
\hline & c. Pesticide & $123,541.67$ \\
\hline & d. Herbicide & $130,916.67$ \\
\hline & e. Labor & 31,250 \\
\hline \multirow[t]{6}{*}{2} & Harvest II & \\
\hline & a. Fertilizer & $139,791.67$ \\
\hline & b. Seeds & 181,875 \\
\hline & c. Pesticide & 105,000 \\
\hline & d. Herbicide & $41,666.67$ \\
\hline & e. Labor & $27,916.67$ \\
\hline \multirow[t]{6}{*}{3} & Harvest III & \\
\hline & a. Fertilizer & 331,250 \\
\hline & b. Seeds & - \\
\hline & c. Pesticide & $121,458.33$ \\
\hline & d. Herbicide & $60,416.66$ \\
\hline & e. Labor & $59,166.67$ \\
\hline \multirow[t]{6}{*}{4} & Harvest IV & \\
\hline & a. Fertilizer & $182,291.67$ \\
\hline & b. Seeds & - \\
\hline & c. Pesticide & $112,083.33$ \\
\hline & d. Herbicide & 35,000 \\
\hline & e. Labor & $110,416.67$ \\
\hline \multirow[t]{6}{*}{5} & Harvest V & \\
\hline & a. Fertilizer & 465,000 \\
\hline & b. Seeds & $37,916.66$ \\
\hline & c. Pesticide & $81,666.66$ \\
\hline & d. Herbicide & $19,166.66$ \\
\hline & e. Labor & $47,916.66$ \\
\hline & Total & $3,251,124.98$ \\
\hline
\end{tabular}

Source: Primary data processed (2017)

\subsubsection{Total Cost}

Total cost is the total amount of production costs used to produce a certain number of outputs that are both fixed costs and variable costs incurred in the cocoa certification program [3]. The total costs incurred in the certification cocoa program can be seen in the table 4 . 
Table 4. Total Cost

\begin{tabular}{|c|c|c|}
\hline No & Cost Types & Amount (IDR) \\
\hline 1 & Fixed Cost & $564,294.247$ \\
\hline 2 & Variable Cost & $3,251,124.98$ \\
\hline & Total & $3,815,419.227$ \\
\hline
\end{tabular}

Source: Primary data processed (2017)

Based on table 4, total costs incurred by farmers from fixed costs and variable costs in the certification cocoa program is IDR 3,815,406. Fixed costs (fixed costs) incurred during the five harvests are the result of calculation total equipment depreciation cost which is about IDR 564,291 while the variable costs (variable cost) is IDR 3,251,115.

Variable costs are the highest costs incurred by farmers while fixed costs are the lowest costs incurred by farmers. This is consistent with finding [2] that, variable costs are costs whose amounts change according to changes in the volume of activities but the cost per unit is fixed, so if the volume of activity is enlarged 2 (two) times then the total cost will also be 2 (two) times from original amount.

\section{Results and Discussion}

\subsection{Income of Certified Cocoa Farmer}

Farm income is the difference between total revenues and total costs. Income is the same as the net profit gained in farming [4]. The amount of income earned by cocoa farmers can be seen in the table 5 .

Table 5. Total of expenditures, income, and profit by certified cocoa farmer

\begin{tabular}{cll}
\hline No & \multicolumn{1}{c}{ Detail } & Amount (IDR) \\
\hline 1 & Acceptance & $20,921,458.3$ \\
& Cost & $564,294.247$ \\
2 & a. Fixed Cost & $3,251,124.98$ \\
& b. Variable Costs & $3,815,419.227$ \\
& c. Total Cost (a+b) & $17,106,039.073$ \\
\hline
\end{tabular}

Source: Primary data processed (2017)

Based on Table 3, it is known that the scale of income obtained by certification farmers per year starting from harvest 1 to harvest 5 can be seen from two types of costs (fixed costs and variable costs), amounting to 20,921,458.3. Variable costs incurred by certification cocoa farmers are greater, this is in accordance with the opinion [2] that variable costs are costs whose amounts change according to changes in the volume of activities, but the per-unit costs are fixed. Net income received by certified cocoa farmers in a year is $17,106,039.073$.

\subsection{Multiple Regression Analysis}

The results of multiple linear regression analysis showed that production (X1). Cocoa production in the certification program significantly affected the income of farmers 
(y) in farmer group Mesa Peolo in West Tapango Village, Tapango Sub-District, Polman District.

Table 6. Results of multiple regression analysis with income as dependent variable and the influence of variables $X 1$ (production), $X 2$ (fixed cost) to variable $Y$ (certified cocoa farmer income).

ANOVA

\begin{tabular}{llrrrrr}
\hline Model & \multicolumn{1}{c}{$\begin{array}{c}\text { Sum of } \\
\text { Squares }\end{array}$} & Df & \multicolumn{1}{c}{$\begin{array}{c}\text { Mean } \\
\text { Square }\end{array}$} & F & Sig. \\
\hline 1 & Regression & $1.305 \mathrm{E} 15$ & 2 & $6.527 \mathrm{E} 14$ & 66.797 & $.000^{\mathrm{a}}$ \\
& Residual & $2.052 \mathrm{E} 14$ & 21 & $9.772 \mathrm{E} 12$ & & \\
& Total & $1.511 \mathrm{E} 15$ & 23 & & & \\
\hline
\end{tabular}

Predictors: (Constant), Fixed cost, Production

Dependent variable: Income

Coefficients

\begin{tabular}{llrrrrr}
\hline \multirow{2}{*}{ Model } & \multicolumn{2}{c}{ Unstandardized Coefficients } & \multicolumn{2}{c}{$\begin{array}{c}\text { Standardized } \\
\text { Coefficients }\end{array}$} & \multirow{2}{*}{ T } & \multirow{2}{*}{ Sig. } \\
\cline { 2 - 4 } & \multicolumn{1}{c}{ B } & \multicolumn{1}{c}{ Std. Error } & \multicolumn{1}{c}{ Beta } & & \\
\hline 1 & (Constant) & 103612.121 & 5113462.498 & & .020 & .984 \\
& Production & 32286.660 & 3098.377 & .962 & 10.421 & .000 \\
& fixed cost & 10.690 & 13.960 & .071 & .766 & .452 \\
\hline
\end{tabular}

Dependent Variable: income

Information: significant on $\mathrm{a}=0.05$

- From the anova test or F test, the F count is 66.797 with a significance level of .000 because the probability $(.000)$ is much smaller than 0.05 , so the regression model can be used to predict that production can affect the income of certified cocoa farmers.

- The regression equation is

- $\mathrm{Y}=103612.121$

$X_{1}=32286.660+10.690 X_{2}$

Which:

$\mathrm{Y}=$ Income

$\mathrm{iX}_{1}=$ Production

$\mathrm{X}_{2}=$ Fixed cost

- The $t$ test is used to examine the significance of constants and the dependent variable (income). As see in the GIS (significance or magnitude of the probability value) which is far below 0.05 . So, it can be said that the regression coefficient is significant, or production has a significant effect on income.

- The regression coefficient value of each independent variable that influences or does not affect the income of certified cocoa farmers in Tapango Barat Village can be explained as follows.

a. Production variable regression coefficient (X1) states that the higher yield of production will influence farmers' income, so the higher yield produced will directly affect the income of certified cocoa farmers with assumption that other variables are constant. 
b. Fixed cost variable regression coefficient $\left(X_{2}\right)$ means that the presence of fixed costs from the results of regression analysis does not directly affect the income of certified cocoa farmers.

\section{Conclusion}

Conclusion Based on the results of the discussion it can be concluded that Mesa Peolo farmer groups who certified by RA (Rain Forest) are not optimal, because there are still a number of farmer group members who did not meet the standards set by the certification program. The income of certified cocoa farmers in Tapango Barat Village was increased 17,106,039.073 each year.

\section{References}

1. Polewali Mandar dalam angka 2012. Polewali: BPS Kabupaten Polewali Mandar; 2014.

2. Harnanto, Zulkifli. Manajemen biaya. Yogyakarta: UPP AMP YKPN; 2003.

3. Dumairy. Perekonomian Indonesia. Jakarta: Erlangga; 1997.

4. Soekartawi. Analisis usaha tani. Jakarta: UI Press; 2006. 